\title{
Predictive Performance of the Winter-Tozer and Derivative Equations for Estimating Free Phenytoin Concentration
}

\author{
Wendy Cheng, Tony K L Kiang, Penny Bring, and Mary H H Ensom
}

\begin{abstract}
Background: The Winter-Tozer equation for estimating free phenytoin concentration is biased and imprecise. Alternative predictive equations are available, but most remain unvalidated.

Objectives: To assess the bias and precision of the Winter-Tozer equation and selected derivative equations in predicting free phenytoin concentration and to derive new equations with better predictive performance.

Methods: A retrospective chart review (for patients with samples drawn for free phenytoin concentration between September 2008 and September 2013) was conducted for 3 subpopulations (critical care, general medicine, neurology) in one hospital. Patients were included if older than 18 years with values for free phenytoin concentration available and were excluded if phenytoin was not at steady state or if they were undergoing hemodialysis or receiving enzyme inhibitors or inducers that would affect phenytoin clearance. The predictive performance measures used were mean prediction error (MPE), root mean square error, and Bland-Altman plots. Spearman rank correlation and multiple linear regression were performed with log-transformed data.
\end{abstract}

Results: In total, 133 patients were included (70 men [53\%]; mean age \pm standard deviation $64 \pm 19$ years; serum creatinine $90.4 \pm 64.0 \mu \mathrm{mol} / \mathrm{L}$; albumin $26.4 \pm 7.0 \mathrm{~g} / \mathrm{L})$. In the combined population, the Winter-Tozer equation (MPE $1.7 \mu \mathrm{mol} / \mathrm{L}, 95 \%$ confidence interval [CI] 1.5 to 1.9 ) and the Anderson equation (MPE $0.5 \mu \mathrm{mol} / \mathrm{L}, 95 \% \mathrm{CI} 0.3$ to 0.7 ) overpredicted free phenytoin concentration, whereas the first Kane equation tended to underpredict free phenytoin (MPE $-0.2 \mu \mathrm{mol} / \mathrm{L}, 95 \% \mathrm{CI}-0.4$ to 0.0 ), and the second Kane equation significantly underpredicted free phenytoin (MPE $-0.3 \mu \mathrm{mol} / \mathrm{L}, 95 \% \mathrm{CI}-0.5$ to -0.1 ). In each subpopulation, the Winter-Tozer equation overpredicted true concentration with greater bias and imprecision. All equations performed poorly in the critical care subpopulation. Only albumin $\left(R^{2}=0.09\right)$ and total phenytoin concentration $\left(R^{2}=0.53\right)$ were correlated with free phenytoin concentration. The equation derived by multiple linear regression exhibited significantly less bias and imprecision than the Winter-Tozer equation in the validation set $(p<0.05)$. A new, user-friendly equation, specific to the authors' patient population, was derived, which had an albumin coefficient of 0.275 .

Conclusions: Relatively poor predictive performance of the Winter-Tozer and derivative equations calls for more precise and less biased equations. The novel equations presented here, which had better predictive performance for free phenytoin concentration and were based on a large sample of adult patients, should be further validated in other institutions.

Keywords: phenytoin, Winter-Tozer equation, predictive performance

\section{RÉSUMÉ}

Contexte : L'équation de Winter-Tozer qui permet d'estimer le taux de phénytoïne libre est biaisée et imprécise. Il existe des équations prédictives de rechange, mais la plupart ne sont pas validées.

Objectifs : Évaluer le biais et la précision de l'équation de WinterTozer et des équations dérivées choisies pour la prédiction du taux de phénytoïne libre et produire de nouvelles équations dotées d'une meilleure capacité prédictive.

Méthodes : Une analyse rétrospective des dossiers médicaux (de patients chez lesquels on a mesuré la concentration de phénytoïne libre entre septembre 2008 et septembre 2013) a été menée au sein de trois sous-populations (soins intensifs, médecine générale et neurologie) dans un seul hôpital. Les patients retenus étaient des adultes âgés de plus de 18 ans dont le dossier contenait des données sur la concentration de phénytoüne libre. Les patients étaient exclus si la concentration de phénytoïne n'était pas à l'équilibre, s'ils étaient traités par hémodialyse ou s'ils prenaient des inhibiteurs ou des inducteurs enzymatiques ayant un effet sur la clairance de la phénytoïne. Les mesures de capacité prédictive comprenaient : l'erreur de prédiction moyenne, l'erreur quadratique moyenne et les graphiques de Bland-Altman. La corrélation des rangs de Spearman et une régression linéaire multiple ont été réalisées à partir de données transformées en log.

Résultats : Au total, 133 patients ont été retenus (70 hommes [53\%]; âge moyen \pm écart-type de $64 \pm 19$ ans; créatinine sérique de 90,4 \pm 64,0 $\mu \mathrm{mol} / \mathrm{L}$; albumine sérique 26,4 $\pm 7,0 \mathrm{~g} / \mathrm{L}$ ). Dans l'ensemble de la population, l'équation de Winter-Tozer (erreur de prédiction moyenne de $1,7 \mu \mathrm{mol} / \mathrm{L}$, intervalle de confiance [IC] à $95 \%$ de 1,5 à 1,9$)$ et l'équation d'Anderson (erreur de prédiction moyenne de $0,5 \mu \mathrm{mol} / \mathrm{L}$, IC à $95 \%$ de 0,3 à 0,7 ) ont surestimé la concentration de phénytoïne libre; la première équation de Kane avait tendance à sous-estimer le taux de phénytoïne libre (erreur de prédiction moyenne de $-0,2 \mu \mathrm{mol} / \mathrm{L}$, IC à $95 \%$ de $-0,4$ à 0,0$)$ ] et la seconde équation de Kane a significativement sous-estimé le taux de phénytoïne libre (erreur de prédiction moyenne de $-0,3 \mu \mathrm{mol} / \mathrm{L}$, IC à $95 \%$ de $-0,5$ à $-0,1)$. Pour chacune des souspopulations, l'équation de Winter-Tozer surévaluait la concentration réelle et était plus biaisée et moins précise. Aucune équation n’a obtenu de bons résultats pour la sous-population en soins intensifs. Seules l'albumine sérique $(\mathrm{R} 2=0,09)$ et la concentration totale de phénytoïne $\left(R^{2}=0,53\right)$ étaient corrélées à la concentration de phénytoïne libre. Léquation obtenue par régression linéaire multiple était beaucoup moins biaisée et imprécise que l'équation de Winter-Tozer parmi l'ensemble de validation $(p<0,05)$. Une nouvelle équation, plus simple à utiliser, spécifique à la population de patients des auteurs, a été produite, avec un coefficient d'albumine de 0,275. 


\section{Can J Hosp Pharm. 2016;69(4):269-79}

Conclusion : Les capacités prédictives relativement mauvaises de l'équation de Winter-Tozer et des équations qui en découlent soulignent l'importance d'adopter des équations plus précises et moins biaisées. Les nouvelles équations mises de l'avant dans la présente étude, équations qui affichent une meilleure capacité prédictive pour la concentration de phénytoïne libre et qui s’appuient sur un important échantillon de patients adultes, doivent être validées dans d'autres établissements.

Mots clés : phénytoïne, équation de Winter-Tozer, capacité prédictive

\section{INTRODUCTION}

$\mathrm{P}$ henytoin is highly protein bound (about 90\%), and its concentration can be affected by changes in protein binding (e.g., because of concurrent therapy with valproic acid, acetylsalicylic acid, sulfonamides, or warfarin), enzyme inhibition (e.g., valproic acid), and enzyme induction (e.g., phenobarbital). ${ }^{1}$ Alterations in protein binding can also occur in hypoalbuminemia (e.g., caused by poor nutrition, critical illness, advanced age, or end-stage diseases). ${ }^{2}$ Total and free phenytoin concentrations are not always consistent with each other. Phenytoin is a low hepatic extraction drug $^{3}$; therefore, total phenytoin concentration is reported to be lower than the therapeutic range in patients with hypoalbuminemia, in whom more of the phenytoin is unbound (free). In this situation, the concentration of free phenytoin (i.e., the pharmacologically active concentration) may actually be normal (i.e., $C_{\mathrm{T}}=\mathrm{k}_{\mathrm{o}} / \mathrm{fCl}_{\mathrm{i}}$ and $C_{\mathrm{F}}=\mathrm{k}_{\mathrm{o}} / \mathrm{Cl}_{\mathrm{i}}$, where $C_{\mathrm{T}}$ is the total concentration, $C_{\mathrm{F}}$ is the free concentration, $\mathrm{k}_{\mathrm{o}}$ is the dose, $\mathrm{f}$ is the free fraction, and $\mathrm{Cl}_{\mathrm{i}}$ is the intrinsic clearance of the drug).

Free phenytoin concentration determines efficacy and toxicity; thus, it is important to have at least an estimate of this value for the purpose of a full clinical assessment, rather than making dose adjustments based on total phenytoin concentration. ${ }^{1}$ Unfortunately, measurement of free phenytoin concentration is not always readily available in clinical laboratories; as such, laboratories commonly report the total phenytoin concentration, which may be misleading for patients with low albumin. ${ }^{4}$ Therefore, it is desirable to be able to estimate free phenytoin concentration through other means., ${ }^{5,6}$ The most common predictive equation for free phenytoin (PHT) is the Winter-Tozer equation (Table 1A):

Predicted free $\mathrm{PHT}=[($ measured total $\mathrm{PHT}) /$

$$
(0.2 \times \text { albumin }+0.1)] \times 0.1
$$

Other equations have been developed theoretically to determine free phenytoin concentration with correction for low albumin, while assuming a normal free fraction of $0.1 .^{5}$ The overall predictive performance of these equations varies. ${ }^{5}$ Thus, other authors continue to validate the Winter-Tozer equation, and some have developed their own equations (Table 2).

Bolt and Gorman ${ }^{7}$ assessed the predictive performance of the Winter-Tozer equation in critical care patients and found it to be imprecise and biased. They noted that low albumin, poor renal and hepatic function, and assay temperature were factors contributing to poor performance. ${ }^{7}$ In particular, these authors observed that the free fraction measured by the assay varied with temperature. Relative to room temperature, body temperature $\left(37^{\circ} \mathrm{C}\right)$ more closely reflected the $10 \%$ free fraction used to develop the Winter-Tozer equation. ${ }^{7}$ Bolt and Gorman ${ }^{7}$ concluded that a significant number of erroneous changes in phenytoin dose were made when the Winter-Tozer equation was used.

In a retrospective study, Kane et al. ${ }^{8}$ analyzed the WinterTozer equation and developed 2 equations for patients in the neurointensive care unit. These equations were found to be better predictors of actual free phenytoin concentration. They recommended further validation of their newly developed equations in other study populations. Anderson et al. ${ }^{9}$ also developed a revised equation, which had less bias and less imprecision than the Winter-Tozer equation. Other studies have evaluated the accuracy of the Winter-Tozer equation and found that it can either underpredict or overpredict actual free phenytoin concentration, especially in patients with hypoalbuminemia (see Table 2). ${ }^{10-12}$

In contrast, 2 other studies showed that the Winter-Tozer equation was predictive of free phenytoin concentration in their respective study populations, with acceptable bias and precision. ${ }^{13,14}$ Although both of these studies actually found a difference in predictive bias and precision of the Winter-Tozer equation in determining free phenytoin concentrations, the authors suggested that this difference might not be clinically significant, considering the cost and lag time for measurement of free phenytoin. ${ }^{14}$ Given the importance of these considerations, it would be beneficial to devise an equation that can more accurately predict free phenytoin concentration in other patient populations, such as those in general medicine, neurology, and critical care wards.

Although many researchers have been able to create and validate an equation or nomogram based on their respective study populations, to the authors' knowledge, these new equations have not been validated at other institutions with other patient populations. ${ }^{8-10,15,16}$ Therefore, the primary objective of this study was to assess the predictive performance of the Winter-Tozer equation and select derivative equations in estimating free phenytoin concentrations in 3 specific patient subpopulations (critical care, general medicine, and neurology). The secondary objectives were to assess the effects of age, sex, estimated glomeru- 


\section{Table 1. Winter-Tozer and Related Predictive Equations}

Equation Designation and Source (A) Original

\begin{tabular}{|c|c|}
\hline Equation 1 (Winter-Tozer) & Predicted free PHT $=\frac{\text { Measured total PHT }}{(0.2 \times \text { albumin }+0.1)} \times 0.1$ \\
\hline Equation 2 (Kane et al. ${ }^{8}$ ) & Predicted free PHT $=\frac{\text { Measured total PHT }}{(0.29 \times \text { albumin }+0.1)} \times 0.1$ \\
\hline Equation 3 (Kane et al. ${ }^{8}$ ) & $\begin{array}{c}x=-0.40378+(\text { measured total PHT } \times 0.17807)+\left(\text { measured total } \mathrm{PHT}^{2}\right. \\
\times-0.00328)+(\text { albumin } \times-0.31312)+(\text { male } \times 0.12362)+(\mathrm{CrCl} \times-0.00174) \\
\text { Predicted free PHT }=\mathrm{e}^{x}\end{array}$ \\
\hline Equation 4 (Anderson et al. ${ }^{9}$ ) & Predicted free PHT $=\frac{\text { Measured total PHT }}{(0.25 \times \text { albumin }+0.1)} \times 0.1$ \\
\hline $\mathrm{MPE}^{5}$ & $\mathrm{MPE}=\frac{1}{n} \Sigma(\mathrm{PE})$ \\
\hline $\mathrm{RMSE}^{5}$ & $\mathrm{RMSE}=\sqrt{\frac{1}{n} \Sigma(\mathrm{PE})^{2}}$ \\
\hline
\end{tabular}

\section{(B) New}

Equation X

$$
\text { Predicted free PHT }=\frac{\text { Measured total PHT }}{(0.26 \times \text { albumin }+0.1)} \times 0.1
$$

Equation $\mathrm{Y} \quad$ Predicted free $\mathrm{PHT}=\frac{\text { Measured total } \mathrm{PHT}}{(0.27 \times \text { albumin }+0.1)} \times 0.1$

\begin{tabular}{|c|c|}
\hline Equation Z & Predicted free $\mathrm{PHT}=$ Measured total PHT \\
\hline
\end{tabular}

Equation W $\quad$ Predicted free PHT $=\frac{\text { Measured total PHT }}{(0.275 \times \text { albumin }+0.1)} \times 0.1$

$\mathrm{CrCl}=$ creatinine clearance, MPE $=$ mean prediction error, $\mathrm{PE}=$ prediction error (predicted concentration minus actual concentration), $\mathrm{PHT}$ = phenytoin, RMSE = root mean square error.

\section{Table 2. Summary of Studies}

\begin{tabular}{|c|c|c|c|c|c|}
\hline Study & Population & Bias & Precision & $\begin{array}{l}\text { Own } \\
\text { Equation? }\end{array}$ & $\begin{array}{c}\text { Winter-Tozer } \\
\text { Equation } \\
\text { Predictive? }\end{array}$ \\
\hline Beck et al. ${ }^{6}$ & General medicine & Overpredicted & Poor & No & No \\
\hline Mauro et al. ${ }^{10}$ & Critical care & $\begin{array}{l}\text { Underpredicted (and } \\
\text { overpredicted) }\end{array}$ & Poor & No & No \\
\hline Krasowski et al. ${ }^{11}$ & Critical care & $\begin{array}{l}\text { Underpredicted } \\
\text { (more than overpredicted) }\end{array}$ & NR & No & No \\
\hline Mlynarek et al. ${ }^{13}$ & Neurology critical care & Overpredicted & Good & No & Yes \\
\hline Dager et al. ${ }^{14}$ & General medicine & Underpredicted & Modest & No & Yes \\
\hline Hong et al. ${ }^{12}$ & General medicine & Overpredicted & Poor & No & No \\
\hline Anderson et al. ${ }^{9}$ & Geriatrics, head trauma & Overpredicted & Poor & Yes & No \\
\hline Kane et al. ${ }^{8}$ & Neurology critical care & Underpredicted & Poor & Yes & No \\
\hline
\end{tabular}

NR $=$ not reported. 
lar filtration rate (eGFR), and total daily dose on the bias and precision of these equations, to assess the number of incorrect or missed dosage changes based on each predictive equation, and to develop and validate our own predictive equation.

\section{METHODS}

A retrospective chart review was conducted at Vancouver General Hospital (Vancouver, British Columbia) for patients with samples drawn for free phenytoin concentration between September 2008 and September 2013. Approval for the study was obtained from the institution's Clinical Research Ethics Board. Any patient older than 18 years of age with a documented value for steady-state free phenytoin concentration available was included. Steady state was based on pre-dose levels on the fifth day of therapy or later (i.e., at least 4 days of therapy with no changes in dose and at least $5 \mathrm{~h}$ since the most recent dose) and was verified with the patient's hospital medication administration record. Phenytoin concentration for all patients was measured with the Dimension Vista System using the PTN Flex reagent cartridge (produced by Siemens Healthcare Diagnostics Inc). Patients were excluded if no free phenytoin concentration and concurrent albumin concentration values were available or if the patients had been undergoing hemodialysis or receiving concomitant therapy with carbamazepine, phenobarbital, and/or valproic acid. These exclusion criteria were applied to ensure that the results of the current study would be comparable to those of previous studies.

The equations of interest were the Winter-Tozer equation, ${ }^{5}$ 2 equations by Kane et al., ${ }^{8}$ and the equation by Anderson et al. ${ }^{9}$ (Table 1A). The mean prediction error (MPE) was used to assess bias, and the root mean square error (RMSE) was used to assess precision. The direction and magnitude of MPE indicate the degree of deviation from the actual value. ${ }^{6}$ For RMSE, only the absolute magnitude is determined; this value is directly associated with the degree of variability in the measurement.

The data were first analyzed for the combined population and subsequently for each subpopulation. Bland-Altman plots were created to allow visual determination of the predictive performance (bias and precision) of equations over a range of concentrations. In this type of plot, the magnitude and direction of deviation from the line of origin represent bias, whereas the extent of deviation (i.e., spread) represents precision. Analytical groups for the secondary analyses included groups subdivided by sex, age ( $\leq 60$ years versus $>60$ years), and renal function as measured by eGFR (divided in increments of $30 \mathrm{~mL} / \mathrm{min}$ ). The cut-offs for age and eGFR were arbitrary. The eGFR values were calculated using the Modification of Diet in Renal Disease equation for serum creatinine obtained from the day closest to when the sample for measurement of phenytoin concentration was drawn. ${ }^{17}$ The various subgroup analyses were undertaken because there may be differences in intrinsic clearance between men and women and between people of older and younger age; also, poor renal function may alter protein binding through uremic products. ${ }^{18}$ The effects of total daily dose were also examined, with 2 dose cut-offs, one at $300 \mathrm{mg}$ and the second at $500 \mathrm{mg}$. This stratification was loosely based on an observation of the common total daily doses. This secondary anaylsis was included because phenytoin exhibits saturable kinetics for absorption and metabolism. The number of potentially erroneous dosage adjustments was calculated for each predictive equation by looking at the difference between predicted and measured values.

The new equations were generated through an iterative process to reduce bias. This iterative process was based on our observation that the albumin coefficient in the denominator of all equations correlated with bias in the overall population. The albumin coefficient in the Winter-Tozer equation is 0.2 (Table 1 ). Subsequently, the entire study population was randomly divided into a development set $(n=83)$ and a validation set $(n=50)$. Spearman rank correlation and multiple linear regression were used to determine correlation with free phenytoin. Logtransformed data (generated with SigmaStat version 3.5) with correlating variables were used to develop a novel regression equation. This equation was then compared with the WinterTozer equation using the validation set for bias and precision.

\section{RESULTS}

\section{Patient Demographic Characteristics}

Altogether, 4502 patients were identified using the hospital computer system. After application of the inclusion and exclusion criteria, 133 patients were included for analysis (Figure 1). Of these, 36 were admitted under critical care, 56 under general medicine, and 41 under neurology (which included general neurology, stroke neurology, and neurosurgery).

The patients included in this study had an average age (mean \pm standard deviation) of $64 \pm 19$ years, serum creatinine of $90.4 \pm 64.0 \mu \mathrm{mol} / \mathrm{L}$, and albumin of $26.4 \pm 7.0 \mathrm{~g} / \mathrm{L}$. The study sample included more men than women (70 [53\%] versus 63 [47\%]). The baseline characteristics of the study sample are summarized in Table 3. General medicine patients tended to be older, neurology patients tended to have lower serum creatinine, and critical care patients tended to have lower albumin concentration. These differences might be explained by the different characteristics of each subpopulation. For example, the typical general medicine patient may be an elderly person with chronic disease, the typical neurology patient may be a younger person with better renal function, and the typical critical care patient would likely be experiencing severe acute illness causing hypoalbuminemia. 


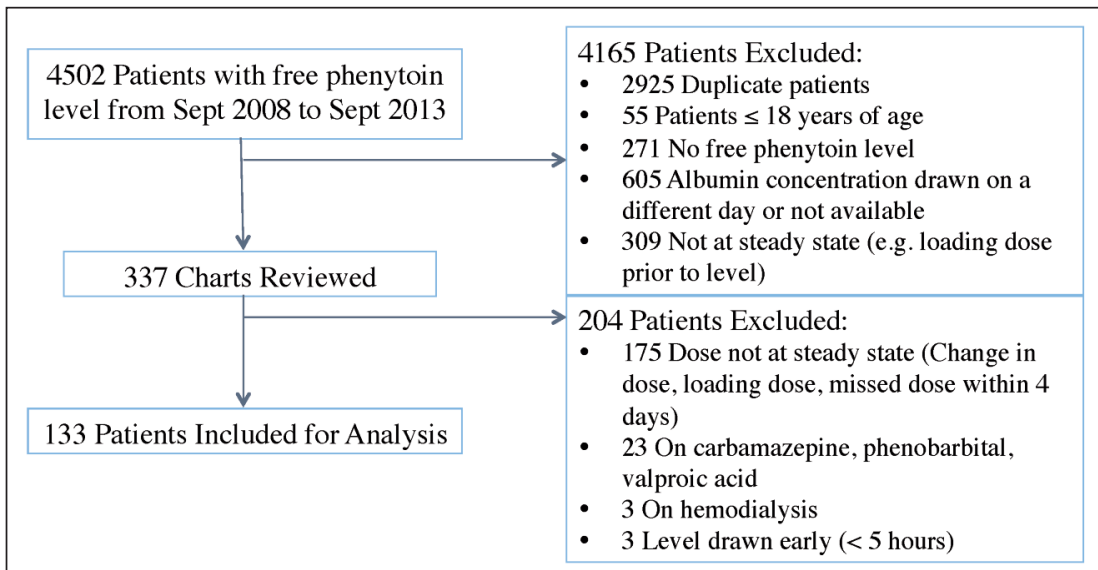

Figure 1. Selection of patients based on application of inclusion and exclusion criteria.

\section{Bias and Precision}

Regarding bias for the overall population, the Winter-Tozer equation (Equation 1) overpredicted, the first Kane equation (Equation 2) tended to underpredict, the second Kane equation (Equation 3) underpredicted, and the Anderson equation (Equation 4) overpredicted actual free phenytoin concentration (Table 4A). For all 3 subpopulations, the Winter-Tozer equation overpredicted free phenytoin concentration.

For the overall population, the Winter-Tozer equation was the least precise in predicting free phenytoin concentration, and all of the other equations had comparable precision (Table 4A). The tendency of the Winter-Tozer equation to be less precise than the other equations was also evident in each patient subpopulation. All of the equations were less precise for the critical care population than for the other 2 subpopulations.

Overall, the Winter-Tozer equation overpredicted free phenytoin concentration and was less precise than the other equations.

\section{Bland-Altman Plots}

Bland-Altman plots were created for all 4 equations for the overall population and for each subpopulation (Figure 2). In all 4 plots, the graphed values for the Winter-Tozer equation were farther away from the line $y=0$ than the values for the other equations, which illustrates greater bias. There was also a trend for all of the equations to poorly predict free phenytoin concentration when the actual concentration was greater than $8 \mu \mathrm{mol} / \mathrm{L}$.

\section{New Equations}

Four new equations were developed on the basis of an observation of correlation between the bias of the Winter-Tozer equation, the second Kane equation, and the Anderson equation and the coefficient of albumin in the denominator of these equations (see Table 1B). The overall bias of these new equations tended to be lower relative to the original equations analyzed (Table 4B). The optimal coefficient for this population, in terms of bias, was 0.275 (Equation W). These new equations had precision comparable to that of the 2 Kane equations and the

Table 3. Overall Baseline Patient Characteristics

Subpopulation; Mean \pm SD or No. (\%) of Patients

\begin{tabular}{|c|c|c|c|c|}
\hline \multirow[b]{2}{*}{ Characteristic } & \\
\hline & $\begin{array}{c}\text { All } \\
(n=133)\end{array}$ & $\begin{array}{c}\text { Critical Care } \\
(n=36)\end{array}$ & $\begin{array}{c}\text { General Medicine } \\
(n=56)\end{array}$ & $\begin{array}{c}\text { Neurology } \\
(n=41)\end{array}$ \\
\hline Age (years) & $64 \pm 19$ & $57 \pm 18$ & $74 \pm 14$ & $56 \pm 20$ \\
\hline Sex, male & $71(53)$ & $26(72)$ & $24(43)$ & $21(51)$ \\
\hline $\mathrm{SrCr}(\mu \mathrm{mol} / \mathrm{L})$ & $90.4 \pm 64.0$ & $104 \pm 74.8$ & $96.8 \pm 75.0$ & $70.3 \pm 16.3$ \\
\hline Albumin (g/L) & $26.4 \pm 7.0$ & $19.0 \pm 5.2$ & $28.4 \pm 5.0$ & $30.3 \pm 5.9$ \\
\hline Oral phenytoin & $119(89)$ & $25(69)$ & $55(98)$ & $39(95)$ \\
\hline Once-daily dosing & $62(47)$ & $8(22)$ & $36(64)$ & $18(44)$ \\
\hline $\begin{array}{l}\text { Free phenytoin concentration } \\
\text { measured as true trough } \\
\text { (within } 1 \mathrm{~h} \text { ) }\end{array}$ & $82(62)$ & $27(75)$ & $27(48)$ & $28(68)$ \\
\hline
\end{tabular}

$\mathrm{SrCr}=$ serum creatinine, SD = standard deviation. 
Table 4. Bias and Precision for Original and New Equations

Subpopulation; Value $(95 \% \mathrm{Cl})$

\begin{tabular}{|c|c|c|c|c|c|c|c|c|}
\hline Equation & & $\begin{array}{c}\text { All } \\
(n=133)\end{array}$ & & $\begin{array}{l}\text { ritical Care } \\
(n=36)\end{array}$ & Gen & $\begin{array}{l}\text { eral Medicine } \\
(n=56)\end{array}$ & & $\begin{array}{l}\text { eurology } \\
(n=41)\end{array}$ \\
\hline $\begin{array}{l}\text { (A) Bias f } \\
\text { Original e }\end{array}$ & E ( mo & & & & & & & \\
\hline Eq. 1 & 1.7 & (1.5 to 1.9 ) & 1.4 & (0.7 to 2.1$)$ & 1.7 & (1.4 to 2.0$)$ & 1.9 & (1.6 to 2.2 ) \\
\hline Eq. 2 & -0.2 & $(-0.4$ to 0.0$)$ & -0.9 & $(-1.6$ to -0.2$)$ & -0.1 & $(-0.3$ to 0.1$)$ & 0.2 & (0.0 to 0.4$)$ \\
\hline Eq. 3 & -0.3 & $(-0.5$ to -0.1$)$ & -1.1 & $(-1.7$ to -0.5$)$ & 5.0 & (4.7 to 5.3 ) & 0.2 & (0.0 to 0.4$)$ \\
\hline Eq. 4 & 0.5 & (0.3 to 0.7$)$ & 0.0 & $(-0.7$ to 0.7$)$ & 0.5 & (0.3 to 0.7$)$ & 0.9 & (0.7 to 1.1$)$ \\
\hline New equa & & & & & & & & \\
\hline Eq. $X$ & 0.3 & (0.1 to 0.5$)$ & & NA & & NA & & NA \\
\hline Eq. Y & 0.1 & $(-0.1$ to 0.3$)$ & & NA & & NA & & NA \\
\hline Eq. Z & -0.1 & $(-0.3$ to 0.1$)$ & & NA & & NA & & NA \\
\hline Eq. W & 0.0 & $(-0.2$ to 0.2$)$ & & NA & & NA & & NA \\
\hline $\begin{array}{l}\text { (B) Precis } \\
\text { Original ec }\end{array}$ & RMS & & & & & & & \\
\hline Eq. 1 & 2.2 & (1.2 to 3.2$)$ & 2.5 & (0.3 to 4.8$)$ & 2.1 & (0.4 to 3.8$)$ & 2.2 & (0.9 to 3.5 ) \\
\hline Eq. 2 & 1.4 & (0.2 to 2.6$)$ & 2.3 & $(-1.8$ to 6.4$)$ & 0.9 & (0.3 to 1.3 ) & 0.7 & (0.5 to 0.9 ) \\
\hline Eq. 3 & 1.3 & (0.5 to 2.1$)$ & 2.0 & $(-0.4$ to 4.4$)$ & 1.1 & (0.4 to 1.8$)$ & 0.8 & (0.6 to 1.0$)$ \\
\hline Eq. 4 & 1.4 & (0.6 to 2.2$)$ & 2.0 & (-0.8 to 4.8$)$ & 1.1 & (0.6 to 1.6$)$ & 1.1 & (0.7 to 1.5$)$ \\
\hline New equa & & & & & & & & \\
\hline Eq. $X$ & 1.3 & (0.4 to 2.2 ) & & NA & & NA & & NA \\
\hline Eq. Y & 1.3 & (0.3 to 2.3 ) & & NA & & NA & & NA \\
\hline Eq. Z & 1.3 & (0.3 to 2.3 ) & & NA & & NA & & NA \\
\hline Eq. W & 1.3 & (0.2 to 2.4$)$ & & NA & & NA & & NA \\
\hline
\end{tabular}

$\overline{\mathrm{Cl}}=$ confidence interval, $\mathrm{MPE}=$ mean prediction error, $\mathrm{NA}=$ not applicable, $\mathrm{RMSE}=$ root mean square error .

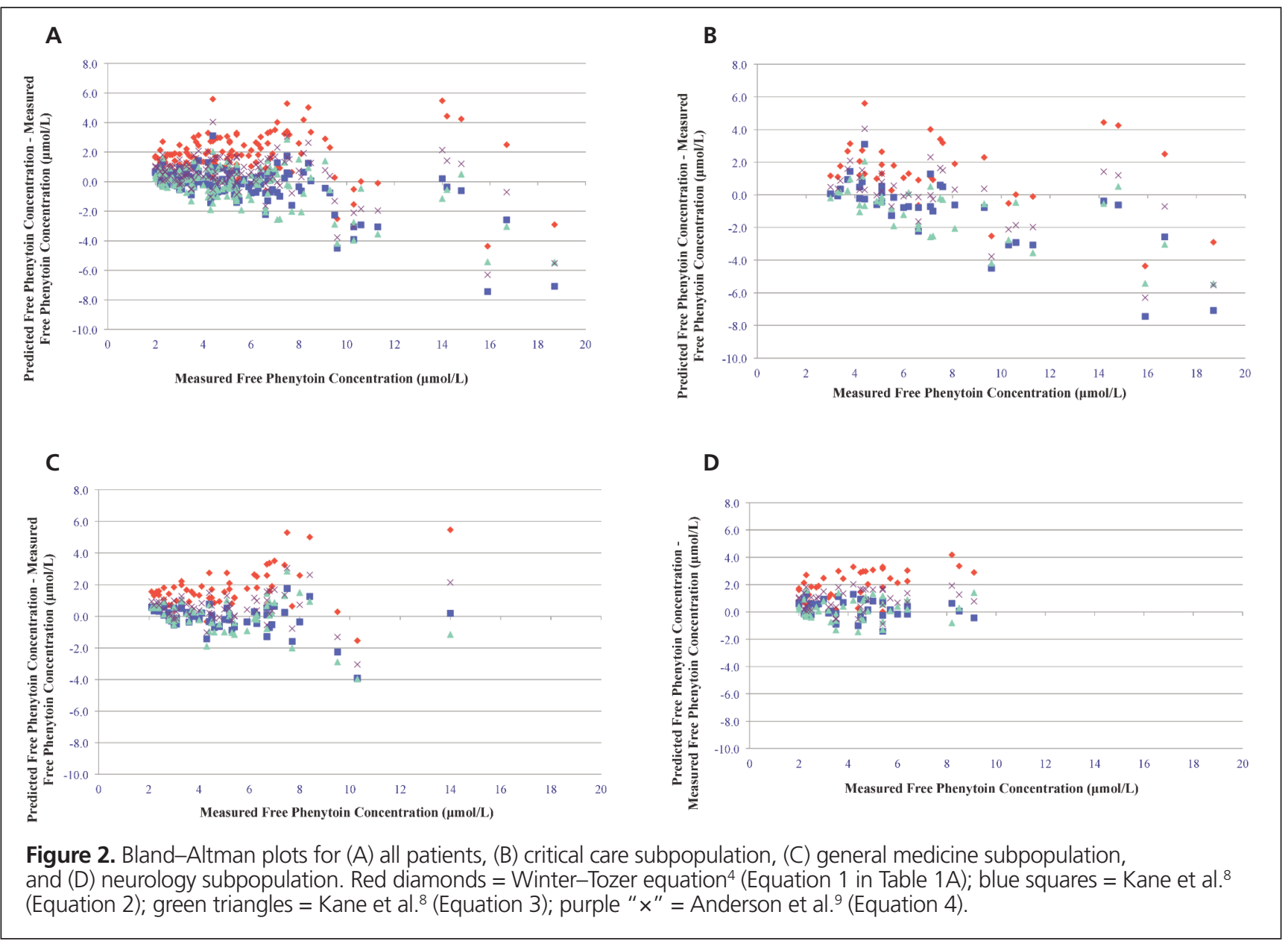




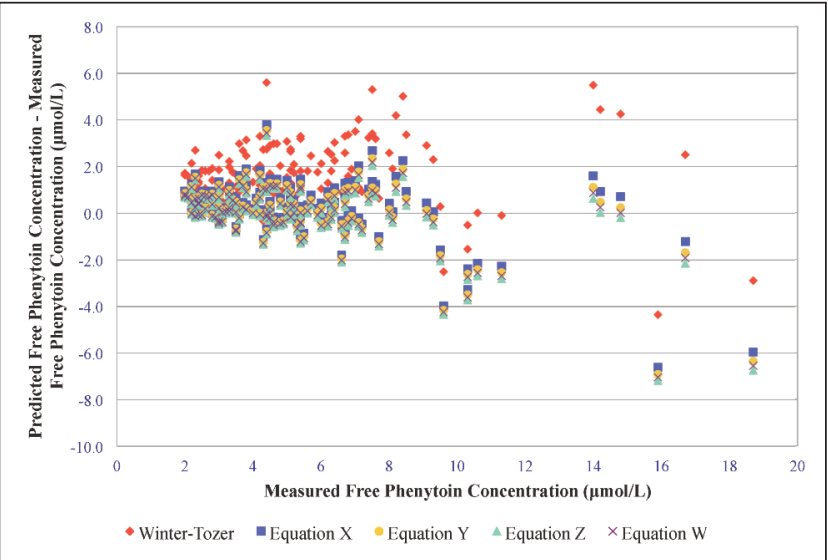

Figure 3. Bland-Altman plot for the new equations. Red diamonds $=$ Winter-Tozer equation ${ }^{4}$; blue squares $=$ Equation $X$; yellow circles $=$ Equation $Y$; green triangles = Equation $Z$; purple " $x$ " = Equation W. Equations $X$ through $W$ are presented in Table 1B.

Anderson equation, and its precision was better than that of the Winter-Tozer equation. The Bland-Altman plot for these new equations (Figure 3) also illustrates their better predictive performance relative to the Winter-Tozer equation.

\section{Regression Equation}

The patients in the development and validation sets were comparable, except for a greater proportion of men in the development set (Table 5). Spearman rank correlation and forward-backward stepwise multiple regression analyses incorporating all variables in the entire sample indicated that only albumin $\left(R^{2}=0.09\right)$ and total phenytoin concentration $\left(R^{2}=0.53\right)$ correlated with free phenytoin concentration. A multiple linear regression equation was generated using these 3 variables with the development set. The following equation $\left(R^{2}=0.85\right)$ was created:

$$
\begin{aligned}
\log (\text { free PHT })= & -0.062-\left[0.956^{*} \log (\text { albumin })\right]+ \\
& \left(1.066^{*} \log [\text { total PHT }]\right)
\end{aligned}
$$

On the basis of the validation set, this equation exhibited less bias and less imprecision than the Winter-Tozer equation (for bias, MPE $-0.03 \pm 0.28 \mu \mathrm{g} / \mathrm{mL}$ versus $0.4 \pm 0.4 \mu \mathrm{g} / \mathrm{mL}$; for precision, RMSE $0.3 \pm 0.2$ versus $0.6 \pm 0.4 \mu \mathrm{g} / \mathrm{mL})(p<0.05)$.

\section{Effects of Age, Sex, eGFR, and Total Daily Dose}

In the secondary analyses based on age (divided at 60 years) and sex, the 2 groups in each analysis were comparable in terms of bias and precision for the overall population with each equation (see Table 6). Within the overall population, analysis by eGFR showed an imbalance among subgroups, which were based on increments of $30 \mathrm{~mL} / \mathrm{min}$. In the smallest subgroup (eGFR $<30 \mathrm{~mL} / \mathrm{min}, n=6$ ), the Winter-Tozer equation tended to have the least bias and imprecision relative to the other equations. In the other subgroups, the Winter-Tozer equation overpredicted free phenytoin and had poorer precision than the other equations. For total daily doses, the Winter-Tozer equation showed the most bias and imprecision relative to the other equations for all the various subgroups. In the subgroup with dose greater than $500 \mathrm{mg}$, all of the equations either overpredicted or tended to overpredict free phenytoin concentration.

\section{Dose Changes}

Considering that the usual therapeutic range for free phenytoin concentration is between 4 and $8 \mu \mathrm{mol} / \mathrm{L}$, concentrations above or below this range may necessitate further clinical assessment and dose adjustment. ${ }^{19}$ Therefore, the difference between the predicted value and the measured free phenytoin concentration that fell above or below this range was calculated for each equation (Table 7). If the predictive equation generated a value greater than $8 \mu \mathrm{mol} / \mathrm{L}$ or less than $4 \mu \mathrm{mol} / \mathrm{L}$ when the actual value was not outside the range of $4-8 \mu \mathrm{mol} / \mathrm{L}$, an unnecessary dosage change might be made. Conversely, if the predictive equation generated a value between 4 and $8 \mu \mathrm{mol} / \mathrm{L}$ when the actual value was outside this range, a required dosage change would be missed. For the overall population, the equation with the most unnecessary or missed dosage changes was the WinterTozer equation (38\% [51 of 133 patients]). The other equations that overpredicted or tended to overpredict free phenytoin concentration (the Anderson equation and new Equations $\mathrm{X}$ and $\mathrm{Y}$ )

\section{Table 5. Baseline Characteristics of Patient Groups Used for Regression Analysis}

\begin{tabular}{lcc} 
& \multicolumn{2}{c}{ Set; Mean \pm SD or No. $(\%)$ of Patients } \\
\cline { 2 - 3 } Characteristic & $\begin{array}{c}\text { Development Set } \\
(\boldsymbol{n}=\mathbf{8 3})\end{array}$ & $\begin{array}{c}\text { Validation Set } \\
(\boldsymbol{n}=\mathbf{5 0})\end{array}$ \\
\hline Age (years) & $62 \pm 21$ & $67 \pm 15$ \\
Sex, male & $51(61)$ & $20(40)$ \\
SrCr $(\mu \mathrm{mol} / \mathrm{L})$ & $88.7 \pm 68.1$ & $93.3 \pm 57.1$ \\
Albumin $(\mathrm{g} / \mathrm{L})$ & $26.6 \pm 7.2$ & $26.1 \pm 6.8$ \\
\hline
\end{tabular}

$\mathrm{SrCr}=$ serum creatinine, SD = standard deviation. 
This single copy is for your personal, non-commercial use only.

For permission to reprint multiple copies or to order presentation-ready copies for distribution, contact CJHP at cjhpedit@cshp.ca

Table 6. Bias and Precision in Secondary Analysis of Age, Sex, eGFR, and Total Daily Dose for Equations 1 through 4*

Equation No.; Value $(95 \% \mathrm{Cl})$

\begin{tabular}{|c|c|c|c|c|}
\hline Factor & Equation 1 & Equation 2 & Equation 3 & Equation 4 \\
\hline \multicolumn{5}{|c|}{$\begin{array}{l}\text { (A) Bias for equations, as MPE ( } \mu \mathrm{mol} / \mathrm{L}) \\
\text { Age (years) }\end{array}$} \\
\hline$\leq 60(n=53)$ & 1.6 (1.2 to 2.0$)$ & $-0.3(-0.8$ to 0.2$)$ & $-0.5(-0.9$ to -0.1$)$ & 0.4 (0.0 to 0.8$)$ \\
\hline$>60(n=80)$ & $1.8(1.5$ to 2.1$)$ & $-0.2(-0.4$ to 0.0$)$ & $-0.1(-0.4$ to 0.2$)$ & $0.5(0.3$ to 0.7$)$ \\
\hline \multicolumn{5}{|l|}{ Sex } \\
\hline Male $(n=71)$ & 1.7 (1.3 to 2.1$)$ & $-0.2(-0.6$ to 0.2$)$ & $-0.1(-0.4$ to 0.2$)$ & 0.5 (0.2 to 0.8$)$ \\
\hline Female $(n=62)$ & $1.7(1.4$ to 2.0$)$ & $-0.2(-0.5$ to 0.1$)$ & $-0.4(-0.7$ to -0.1$)$ & 0.5 (0.2 to 0.8$)$ \\
\hline \multicolumn{5}{|l|}{ eGFR (mL/min) } \\
\hline$<30(n=6)$ & $-0.1(-2.4$ to 2.2$)$ & $-2.5(-5.0$ to 0.0$)$ & $-1.3(-3.5$ to 0.9$)$ & $-1.6(-4.0$ to 0.8$)$ \\
\hline $30-59(n=27)$ & $1.3(0.8$ to 1.8$)$ & $-0.5(-0.9$ to -0.1$)$ & $-0.3(-0.8$ to 0.2$)$ & $0.2(-0.2$ to 0.6$)$ \\
\hline $60-89(n=54)$ & $2.0(1.7$ to 2.3$)$ & $-0.1(-0.5$ to 0.3$)$ & $0.0(-0.4$ to 0.4$)$ & $0.7(0.4$ to 1.0$)$ \\
\hline$\geq 90(n=46)$ & $3.1(2.7$ to 3.5$)$ & $0.1(-0.1$ to 0.3$)$ & $-0.6(-0.9$ to -0.3$)$ & $1.2(0.9$ to 1.5$)$ \\
\hline \multicolumn{5}{|l|}{ Dose (mg) } \\
\hline$<300(n=18)$ & 1.7 (1.1 to 2.3 ) & $-0.2(-0.5$ to 0.1$)$ & $-0.3(-0.8$ to 0.2$)$ & 0.5 (0.1 to 0.9$)$ \\
\hline $300(n=53)$ & 1.5 (1.0 to 2.0$)$ & $-0.6(-1.1$ to -0.1$)$ & $-0.6(-1.0$ to -0.2$)$ & $0.2(-0.3$ to 0.7$)$ \\
\hline $301-499(n=43)$ & $1.7(1.3$ to 2.1$)$ & $-0.1(-0.4$ to 0.2$)$ & $-0.1(-0.4$ to 0.2$)$ & $0.6(0.3$ to 0.9$)$ \\
\hline$>500(n=19)$ & 2.3 (1.7 to 2.9$)$ & $0.2(-0.4$ to 0.8$)$ & $0.3(-0.3$ to 0.9$)$ & $1.0(0.5$ to 1.5$)$ \\
\hline
\end{tabular}

\section{(B) Precision for equations, as RMSE}

Age (years)

$>60(n=80)$

$2.2(1.1$ to 3.3$)$

$1.7(-1.1$ to 4.5$)$

$1.5(-0.1$ to 3.1$)$

$1.6(-0.3$ to 3.5$)$

Sex

Male $(n=71)$ $2.8(1.3$ to 4.3$)$ $1.4(0.8$ to 2.0$)$ 1.5 (0.9 to 2.1$)$ 1.5 (0.9 to 2.1$)$

Female $(n=62)$

$2.3(0.8$ to 3.8$)$

2.3 (0.8 to 3.8)

$1.3(0.2$ to 2.4$)$

1.5 (0.1 to 2.9)

eGFR ( $\mathrm{mL} / \mathrm{min})$ 2.2 (0.8 to 3.6) $1.4(0.5$ to 2.3$)$ $1.2(0.6$ to 1.8$)$

\begin{tabular}{lllll}
$<30(n=6)$ & $2.6(-3.0$ to 8.2$)$ & $3.8(-13.5$ to 21.1$)$ & $2.9(-7.0$ to 12.8$)$ & $3.2(-9.2$ to 15.6$)$ \\
$30-59(n=27)$ & $1.9(-0.4$ to 4.2$)$ & $1.2(-0.1$ to 2.5$)$ & $1.3(-0.1$ to 2.7$)$ & $1.1(0.2$ to 2.0$)$ \\
$60-89(n=54)$ & $2.4(1.1$ to 3.7$)$ & $1.3(-0.5$ to 3.1$)$ & $1.3(0.1$ to 2.5$)$ & $1.4(0.3$ to 2.5$)$ \\
$\geq 90(n=46)$ & $2.9(1.0$ to 4.8$)$ & $1.0(0.6$ to 1.4$)$ & $1.3(0.9$ to 1.7$)$ & $1.5(0.8$ to 2.2$)$ \\
\hline Dose $(m g)$ & $2.1(-1.2$ to 5.4$)$ & $0.7(0.4$ to 1.0$)$ & $1.2(0.4$ to 2.0$)$ & $1.0(0.5$ to 1.5$)$ \\
$<300(n=18)$ & $2.3(0.6$ to 4.0$)$ & $1.8(-1.0$ to 4.6$)$ & $1.6(-0.1$ to 3.3$)$ & $1.7(-0.1$ to 3.5$)$ \\
$300(n=53)$ & $2.0(0.7$ to 3.3$)$ & $0.9(0.0$ to 1.8$)$ & $0.9(0.1$ to 1.7$)$ & $1.1(0.4$ to 1.8$)$ \\
$301-499(n=43)$ & $2.6(-0.6$ to 5.8$)$ & $1.2(-0.1$ to 2.5$)$ & $1.3(0.0$ to 2.6$)$ & $1.5(-0.2$ to 3.2$)$ \\
\hline $500(n=19)$ & & &
\end{tabular}

$\overline{\mathrm{Cl}}=$ confidence interval, eGFR = estimated glomerular filtration rate, MPE = mean prediction error, RMSE = root mean square error.

*The 4 equations are presented in Table $1 \mathrm{~A}$.

had more unnecessary or missed dosage changes than the other equations, such as Equations $\mathrm{Z}$ and W.

\section{DISCUSSION}

It is important for clinical pharmacists to have an accurate tool to predict free phenytoin concentration, because this drug has a narrow therapeutic index and wide interpatient variability. Using an equation to estimate the patient's free phenytoin concentration may minimize delays in dosage adjustments, as measurements of free phenytoin concentration may not be readily available, either because the laboratory lacks the analytical reagent kit or because samples may not be processed at certain times (e.g., during the weekend). Also, the cost of measuring free phenytoin concentration is about double the cost of measuring total phenytoin concentration, because of the need for measured total phenytoin concentration and a filter. However, if an estimating equation is validated to be accurate, direct measure- ment of free phenytoin concentration may not be necessary. In some health care facilities, measuring actual free phenytoin concentration may not even be feasible, leaving the facility to rely entirely on predictive equations.

In this study, the Winter-Tozer equation had the most bias (overpredicting free phenytoin concentration by an overall value of $1.7 \mu \mathrm{mol} / \mathrm{L}$ ) and the most imprecision relative to select derivative equations (from previous studies) and the new equations that were derived here. This finding is consistent with those of most other studies that have assessed the predictive performance of the Winter-Tozer equation, , $^{70-13,15}$ including those by Kane et al. ${ }^{8}$ and Anderson et al. ${ }^{9}$ The bias of the Winter-Tozer equation would be a concern in this study if the actual free phenytoin concentration were between 6.3 and $8 \mu \mathrm{mol} / \mathrm{L}$ or between 2.3 and $4 \mu \mathrm{mol} / \mathrm{L}$, as these are the ranges where dose changes may be made unnecessarily. This conclusion is based on the usual therapeutic range of free phenytoin, 4 to 
This single copy is for your personal, non-commercial use only.

For permission to reprint multiple copies or to order presentation-ready copies for distribution, contact CJHP at cjhpedit@cshp.ca

Table 7. Erroneous Dose Changes Based on Predictive Equations $(n=133)$

\begin{tabular}{|c|c|c|c|c|c|c|c|c|c|}
\hline \multirow{2}{*}{$\begin{array}{l}\text { No. of Measurements } \\
\text { Outside Target Range }\end{array}$} & \multirow{2}{*}{$\begin{array}{l}\text { Measured } \\
\text { Value }\end{array}$} & \multicolumn{8}{|c|}{ Equation Designator; Estimated Values } \\
\hline & & 1 & 2 & 3 & 4 & $\mathrm{X}$ & $\mathrm{Y}$ & Z & W \\
\hline $\begin{array}{l}\text { No. of measurements with } \\
\text { free phenytoin concentration } \\
>8 \mu \mathrm{mol} / \mathrm{L}\end{array}$ & 18 & 43 & 16 & 15 & 26 & 23 & 20 & 16 & 19 \\
\hline $\begin{array}{l}\text { No. of decreases in dose } \\
\text { that were missed or } \\
\text { unnecessary }\end{array}$ & NA & 25 & 2 & 3 & 8 & 5 & 2 & 2 & 1 \\
\hline $\begin{array}{l}\text { No. of measurements with } \\
\text { free phenytoin concentration } \\
<4 \mu \mathrm{mol} / \mathrm{L}\end{array}$ & 47 & 21 & 48 & 49 & 36 & 38 & 39 & 44 & 43 \\
\hline $\begin{array}{l}\text { No. of increases in dose } \\
\text { that were missed or } \\
\text { unnecessary }\end{array}$ & NA & 26 & 1 & 2 & 11 & 9 & 8 & 3 & 4 \\
\hline $\begin{array}{l}\text { Total no. } \\
\text { (and \% of } 133 \text { patients)* }\end{array}$ & NA & $51(38)$ & $3(2)$ & $5(4)$ & $19(14)$ & $14(11)$ & $10(8)$ & $5(4)$ & $5(4)$ \\
\hline
\end{tabular}

$8 \mu \mathrm{mol} / \mathrm{L} .{ }^{19}$ However, the proposed therapeutic range is not absolute. Some patients may require a higher or lower concentration to remain free of seizures. Thus, clinical assessment of the patient for efficacy and toxicity should be the primary factor in making dosage adjustments. In most cases, use of the WinterTozer equation may lead to an unnecessary change in the phenytoin dose, or to missing a required change. The likelihood of the Winter-Tozer equation causing an erroneous dosage change, as determined here, was similar to that found by Bolt and Gorman. ${ }^{7}$ The greater imprecision with the Winter-Tozer equation suggests that it will likely not predict free phenytoin concentration accurately. Thus, there is a need for a new equation with better predictive performance.

In the critical care subpopulation of the current study, the 2 Kane equations (Equations 2 and 3 in Table 1A) had poorer bias but similar precision relative to the Anderson equation (Equation 4). Both of the Kane equations underpredicted free phenytoin concentration by about $1 \mu \mathrm{mol} / \mathrm{L}$. This underprediction may have been due to the low number of patients in this subpopulation $(n=36)$, their lower average albumin, and/or their poorer renal function relative to patients in the original study. ${ }^{8}$ All of the equations had poorer precision in the critical care subpopulation than in the other subpopulations and the overall population. This suggests that there may be other factors in the critical care population affecting free phenytoin concentration that the equations did not take into account. For example, Boucher et al. ${ }^{20}$ described changes in intrinsic clearance of phenytoin in critical care patients secondary to changes in levels of stress hormones (e.g., norepinephrine) and cytokines. The concentrations of plasma proteins (e.g., reduced albumin) may also change in this patient population. ${ }^{20}$ Worsened renal function may cause an increase in the free fraction of phenytoin through decreased binding affinity of albumin for phenytoin. ${ }^{18}$ This effect on albumin during renal failure is caused by the accumulation of uremic products. ${ }^{18}$
All of these factors can change the free fraction of phenytoin. At this time, there does not seem to be a predictive equation that can predict free phenytoin concentration in the critical care population with minimal bias and imprecision.

In the general medicine population of the current study, Equation 3, proposed by Kane et al., ${ }^{8}$ overpredicted free phenytoin concentration by $5 \mu \mathrm{mol} / \mathrm{L}$. This significant bias may be present because the equation takes into account albumin, sex, and creatinine clearance, and the equation was developed for patients in the neurointensive care unit, not general medicine patients. The current results differ from those of Kane et al., ${ }^{8}$ who found that their multiple regression equation predicted free phenytoin concentration better than the Winter-Tozer equation. The multiple factors in Equation 3 may work specifically for the patient population in the original study. ${ }^{8}$ This inconsistency suggests that there may be differences between subpopulations that necessitate different predictive equations.

The effect of the specific population for which the Kane equations were designed can be seen in the neurology subpopulation of the current study. This subpopulation included patients who were admitted to the neurointensive care unit, although most patients were in the general neurology ward. For this subpopulation, both Equations 2 and 3 had reduced bias (tended to overpredict) and had the least imprecision relative to the other 2 equations. In a cohort study, Brown et al. ${ }^{21}$ applied the 2 Kane equations $^{8}$ to patients receiving neurointensive care. Interestingly, they found poorer precision with the Kane equations than with the Winter-Tozer equation. ${ }^{21}$ Kane et al. ${ }^{22}$ suggested that the difference might have been due to a difference in assay temperatures $\left(25^{\circ} \mathrm{C}\right.$ in their study ${ }^{8}$ versus $37^{\circ} \mathrm{C}$ in the study by Brown et al. ${ }^{21}$ ). However, given that this study ${ }^{8}$ and Anderson et al. ${ }^{9}$ both used an assay temperature of $25^{\circ} \mathrm{C}$ and the Anderson equation displayed poorer trends for bias and precision than the Kane equations, assay temperature does not fully explain this 
difference in results. This situation emphasizes the need to derive equations for predicting free phenytoin concentration that are specific to each patient population. In the neurology subpopulation, there may be some benefit to using Equation 2 rather than the Winter-Tozer equation. However, further validation studies of this equation with this patient population are needed.

No difference was observed in the predictive performance of any equation in relation to sex or age groups. Although differences in pharmacokinetics between elderly and younger patients may be expected, they were not observed in this study. This finding may be due to use of 60 years as the cut-off, which might not be suitable for isolating the elderly population.

The observed effects on predictive performance of the equations with different eGFR values and total daily doses may not be clinically significant. These subgroups had unbalanced numbers of patients, which resulted in some subgroups being very small. Therefore, these differences may be due to chance.

The new equations that were developed for this patient population, while retaining similar precision to the derivative equations, were able to reduce overall bias. Other factors that may affect the precision of the predictive equations were not accounted for in the Winter-Tozer equation. The newly proposed albumin coefficient of 0.275 , which reduced bias, may better aid clinical pharmacists in providing patient care. Similarly, the regression equation may be a suitable alternative tool for the study institution's patient population, because it had reduced bias and imprecision relative to the Winter-Tozer equation.

This study was limited by its retrospective nature. A prospective study would allow control over experimental conditions (e.g., sample collection time, albumin sampling time) to minimize random variability, such as unnecessary data noise. A prospective study would also allow testing of all relevant variables affecting the predictive performance of the equations with sufficient statistical power to draw meaningful conclusions. Overall, such a study would provide confidence in using an alternative equation to the Winter-Tozer equation to predict free phenytoin concentrations. Furthermore, although the current study's sample size was comparable to those of other similar studies, it did not appear reasonable to develop individual equations for each subpopulation because of their small sample sizes. Finally, the exclusions will affect the applicability of the study results to populations other than those in this study.

\section{CONCLUSION}

This study has validated the poor predictive performance of the Winter-Tozer equation in terms of bias and precision. Our analysis of select subpopulations has indicated that newer equations are warranted to better predict free phenytoin concentration, especially in the critical care subpopulation. This study resulted in derivation of a new, user-friendly equation, specific to the study institution's patient population (general medicine, critical care, and neurology), with an albumin coefficient of 0.275 ; this equation should be further validated by other institutions. Future studies would be beneficial to develop individual equations for various other subpopulations.

\section{References}

1. Perucca E. Plasma protein binding of phenytoin in health and disease: relevance to therapeutic drug monitoring. Ther Drug Monitor. 1980;2(4): 331-44.

2. Gatta A, Verardo A, Bolognesi M. Hypoalbuminemia. Intern Emerg Med. 2012;7(3):S193-9.

3. Wilkinson GR, Shand DG. Commentary: a physiological approach to hepatic drug clearance. Clin Pharmacol Ther. 1975;18(4):377-90.

4. Therapeutic serum concentrations and sampling guidelines. In: Pediatric drug dosage guidelines. Vancouver (BC): BC Children's and Women's Hospital; 2015 [cited 2015 Aug 31]. pp. 225-228. Available from: www.pedmed.org/ DrugApp/Supplementary/Therapeutic\%20Drug\%20Monitoring.pdf

5. Tozer TN, Winter ME. Phenytoin. In: Schentag JJ, editor. Applied pharmacokinetics: principles of therapeutic drug monitoring. 3rd ed. Vancouver (WA): Applied Therapeutics; 1992. pp. 25.1-25.44.

6. Beck DE, Farringer JA, Ravis WR, Robinson CA. Accuracy of three methods for predicting concentrations of free phenytoin. Clin Pharm. 1987;6(11): 888-94.

7. Bolt J, Gorman SK. Precision, bias, and clinical utility of the Sheiner-Tozer equation to guide phenytoin dosing in critically ill adults. J Clin Pharmacol. 2013;53(4):451-5.

8. Kane SP, Bress AP, Tesoro EP. Characterization of unbound phenytoin concentrations in neurointensive care unit patients using a revised WinterTozer equation. Ann Pharmacother. 2013;47(5):628-36.

9. Anderson GD, Pak C, Doane KW, Griffy KG, Temkin NR, Wilensky AJ, et al. Revised Winter-Tozer equation for normalized phenytoin concentrations in trauma and elderly patients with hypoalbuminemia. Ann Pharmacother. 1997;31(3):279-84.

10. Mauro LS, Mauro VF, Bachmann KA, Higgins JT. Accuracy of two equations in determining normalized phenytoin concentrations. DICP. 1989;23(1):64-8.

11. Krasowski MD, Penrod LE. Clinical decision support of therapeutic drug monitoring of phenytoin: measured versus adjusted phenytoin plasma concentrations. BMC Med Inform Decis Mak. 2012;12(1):7.

12. Hong JM, Choi YC, Kim WJ. Differences between the measured and calculated free serum phenytoin concentrations in epileptic patients. Yonsei Med J. 2009;50(4):517-20.

13. Mlynarek ME, Peterson EL, Zarowitz BJ. Predicting unbound phenytoin concentrations in the critically ill neurosurgical patient. Ann Pharmacother. 1996;30(3):219-23.

14. Dager WE, Inciardi JF, Howe TL. Estimating phenytoin concentrations by the Sheiner-Tozer method in adults with pronounced hypoalbuminemia. Ann Pharmacother. 1995;29(7-8):667-70.

15. Pospisil J, Pelclová D. A graphical nomogram method for predicting toxic concentrations of unbound phenytoin. Int J Clin Pharmacol Ther. 1994; 32(3):122-5.

16. Rhoney DH, Leader WG, Chandler MH. Modified Michaelis-Menten equation for estimating unbound-phenytoin concentrations. Clin Pharm. 1993;12(12):913-7.

17. Levey AS, Bosch JP, Lewis JB, Greene T, Rogers N, Roth D. A more accurate method to estimate glomerular filtration rate from serum creatinine: a new prediction equation. Modification of Diet in Renal Disease Study Group. Ann Intern Med. 1999;130(6):461-70.

18. von Winckelmann SL, Spriet I, Willems L. Therapeutic drug monitoring of phenytoin in critically ill patients. Pharmacotherapy. 2008;28(11):1391-400.

19. Patsalos PN, Berry DJ, Bourgeois BF, Cloyd JC, Glauser TA, Johannessen SI, et al. Antiepileptic drugs - best practice guidelines for therapetuic drug monitoring: a position paper by the subcommission on therapeutic drug monitoring, ILAE Commission on Therapeutic Strategies. Epilepsia. 2008;49(7):1239-76. 
20. Boucher BA, Wood GC, Swanson JM. Pharmacokinetic changes in critical illness. Crit Care Clin. 2006;22(2):255-71.

21. Brown AL, Sangha KS, Mueller EW, Kaur D, Keegan SP. Response to "Characterization of unbound phenytoin concentrations in neurointensive care unit patients using a revised Winter-Tozer equation” by Sean P. Kane, Adam P. Bress, and Eljim P. Tesoro. Ann Pharmacother. 2013;47(10): 1374-5.

22. Kane SP, Bress AP, Tesoro EP. Author response to Brown et al characterization of free phenytoin concentration in neurointensive care unit patients using a revised Winter-Tozer equation. Ann Pharmacother. 2013;47(12):1744.

Wendy Cheng, BSc(Pharm), ACPR, is a Clinical Pharmacist, Department of Pharmacy, Vancouver General Hospital, Vancouver, British Columbia.

Tony K L Kiang, BSc(Pharm), PhD, ACPR, is a Clinical Pharmacy Specialist, Department of Pharmacy, Vancouver General Hospital, Vancouver, British Columbia.
Penny Bring, BSC(Pharm), ACPR, PharmD, is a Clinical Pharmacy Specialist, Department of Pharmacy, Surrey Memorial Hospital, Surrey, British Columbia.

Mary H H Ensom, BS(Pharm), PharmD, FASHP, FCCP, FCSHP, FCAHS, is Professor, Faculty of Pharmaceutical Sciences and Distinguished University Scholar, The University of British Columbia, and Clinical Pharmacy Specialist, Department of Pharmacy, Children's and Women's Health Centre of British Columbia, Vancouver, British Columbia.

Competing interests: None declared.

\section{Address correspondence to:}

Dr Tony Kiang

CSU - Pharmaceutical Sciences

Vancouver General Hospital

855 West 12th Avenue

Vancouver BC V5Z $1 \mathrm{M} 9$

e-mail: tkiang@gmail.com

Funding: None received.

\section{BEST..is better}

\section{One resource for all types of compounding by pharmacies}

\section{WHAT'S INSIDE?}

- Information for pharmacists, pharmacy technicians, planners, architects, engineers-and others who are involved in decisions or activities that affect compounding

- Guidelines for aseptic compounding, non-aseptic compounding, and compounding which involves hazardous drugs-including radiopharmaceuticals

- Best and leading guidelines on topics such as training, planning and designing the physical environment, developing an air quality strategy, cleaning and decontaminating areas, monitoring the environment, garbing and hand hygiene, developing compounding procedures, documenting, and much more-all in only 230 pages
Learn what best looks like: add

this publication to your library!
Canadian Society of Hospital Pharmacists Société canadienne des pharmaciens d'hôpitaux 